hyperglycaemia, which deleteriously stresses their function (fig 4). Partial return of impaired insulin secretion has been noted after treatment of acute episodes of hyperglycaemia, ${ }^{13}$ but our results suggest that decreasing even slightly raised plasma glucose levels improves the efficiency of insulin secretion.

A constant basal insulin supplement in patients with mild diabetes reduces the basal plasma glucose concentration to normal. This allows the $\beta$-cell to function more efficiently, although it is unlikely that a completely normal response can be obtained. The total plasma glucose area after the standard breakfast was improved in proportion to the degree of basal hyperglycaemia when the fasting plasma glucose was over $5.8 \mathrm{mmol} / 1(105 \mathrm{mg} / 100 \mathrm{ml})$. The incremental plasma glucose response was increased and this may be secondary to the decreased overnight portal vein insulin concentration, allowing enhanced hepatic glucose efflux.

In rats prolonged hyperglycaemia causes degranulation of the $\beta$-cells ${ }^{14}$ and this may occur in diabetes in man. Chronic hyperglycaemia in cats sometimes induces permanent diabetes. ${ }^{15}$ It has been suggested that prolonged hyperglycaemia could irrevocably "exhaust" the islets and that improved treatment with insulin may prevent this. ${ }^{16}$ If dogs are treated with insulin to prevent hyperglycaemia induced by anterior pituitary extracts insulin depletion of the pancreas can be prevented. ${ }^{17}$

Attainment of normoglycaemia is usually the aim in the treatment of diabetes as the long-term complications are likely to be secondary to disturbed metabolism. We have shown that normoglycaemia also helps 3 -cell function. Basal insulin supplements allow correction of the raised basal plasma glucose of diabetes with minimal risk of hypoglycaemia. They could be provided by injection of a very long-acting insulin, and this simple form of insulin replacement treatment might be beneficial in patients with mild diabetes.

We thank Dr T D R Hockaday and Professor D J Weatherall for allowing us to study patients under their care and for their support; Miss P Harding and Mrs C Uren for their help; and the Oxford Regional Health Authority (Teaching) and the British Diabetes Association for grants.

\section{References}

1 Turner, R C, et al, submitted for publication.

2 Turner, R C, Harris, E, and Uren, C, submitted for publication.

3 McCarthy, S, Harris, E, and Turner, R C, submitted for publication.

4 Lerner, R L, and Porte, D, fournal of Clinical Investigation, 1972, 51, 1624

5 Turner, R C, and Johnson, P C, Lancet, 1973, 1, 1483.

${ }^{6}$ Albano, J D M, et al, Acta Endocrinologica, 1972, 70, 487.

7 Statistical Bulletin, Metropolitan Life Insurance Company, 1959, 40, November-December.

' Sando, H, Kanazawa, Y, and Kuzuya, T, American fournal of Physiology, 1970, 218, 1357.

${ }^{9}$ Shen, S, Reaven, R, and Farqhuar, T V, fournal of Clinical Investigation, $1970,49,2151$.

${ }^{10}$ Lerner, R L, and Porte, D, fournal of Clinical Investigation, 1971, 33, 409.

11 Pelkonen, R, Taskinen, M, and Nikkilä, E A, fournal of Clinical Endocrinology and Metabolism, 1974, 39, 418.

12 Turner, R C, et al, submitted for publication

${ }^{13}$ Foucar, E, and Field, J B, fournal of Clinical Endocrinology and Metabolism, 1972, 35, 288.

14 Carpenter, A M, and Lazarow, A, Diabetes, 1967, 16, 493

15 Dohan, F C, and Lukens, F D W, Endocrinology, 1948, 42, 244.

${ }^{16}$ Haist, R E, Campbell, J, and Best, C H, New England fournal of Medicine, 1940, 223, 607 .

17 Campbell, J, et al, American fournal of Physiology, 1940, 129, 328.

\title{
Effect of triamterene on leucocyte sodium and potassium levels in heart disease
}

\author{
E K DONALDSON, J PATRICK，S SIVAPRAGASM， M O WOO MING， G A O ALLEYNE
}

British Medical fournal, 1976, 1, 1254-1255

\section{Summary}

Sodium and potassium levels in plasma and leucocytes and the sodium efflux rate constants of leucocytes were measured in patients with congenital heart disease not on treatment, patients with valvular heart disease being treated with digoxin and conventional diuretics, and patients with valvular heart disease receiving digoxin and either conventional diuretics or triamterene or both. The group being treated with digoxin and conventional diuretics showed low cellular potassium levels, low sodium efflux rate constants, and a rise in cellular sodium levels. Patients given triamterene showed a rise in potassium levels in plasma and cells and in the sodium efflux rate constant.

University of the West Indies, Kingston 7, Jamaica

E K DONALDSON, MB, BS, research fellow, department of medicine

J PATRICK, MB, MRCP, research fellow, tropical metabolism research unit, and honorary consultant physician

S SIVAPRAGASM, MB, FFARCS, senior lecturer in anaesthetics

$M$ O WOO MING, FRCS, reader in surgery

G A O ALLEYNE, MD, FRCP, professor of medicine

\section{Introduction}

Heart failure is associated with abnormalities of intracellular electrolytes, total exchangeable potassium, and whole-body potassium. ${ }^{1-4}$ Diuretics and cardiac glycosides are only two of the factors that may affect intracellular electrolytes in heart failure. Much emphasis has been placed on the role of conventional diuretics in producing potassium depletion, but they do not appear to cause a significant reduction in whole-body or leucocyte potassium when used in accepted doses. ${ }^{35}$ Cardiac glycosides, however, interfere with potassium and sodium homoestasis at the cellular level. Ouabain inhibits the active component of sodium efflux in both red cells ${ }^{6}$ and leucocytes, ? causing a fall in intracellular potassium and a rise in intracellular sodium. It also reduces myocardial potassium. ${ }^{8}$ Acetylstrophanthin increases potassium outflow in the coronary sinus blood of dogs, ${ }^{9}$ and digoxin in the usual clinical doses reduces red blood cell potassium. ${ }^{1011}$

When used in therapeutic doses, triamterene, a non-steroidal, potassium-retaining diuretic, increases serum potassium levels in man and reduces urinary potassium excretion. ${ }^{12-14}$ Possibly such a drug could also lead to a rise in intracellular potassium. This would be particularly valuable in pat $i$ ents on digitalis and those undergoing open-heart surgery, as prolonged cardiopulmonary bypass may be associated with a fall in myocardial potassium of up to $50^{\circ},{ }^{15}$ which has been causally related to the development of cardiac arrhythmias. ${ }^{16}$

We have measured the leucocyte sodium and potassium 
Mean results of measurements in the three groups of patients ( $\pm S E$ of mean)

\begin{tabular}{|c|c|c|c|c|c|c|c|c|}
\hline \multirow{2}{*}{ Group } & \multirow{2}{*}{ No } & \multirow{2}{*}{$\begin{array}{l}\text { Cell water } \\
(1 / \mathrm{kg} \mathrm{DS})\end{array}$} & \multicolumn{2}{|c|}{ Leucocyte potassium } & \multicolumn{2}{|c|}{ Leucocyte sodium } & \multirow{2}{*}{$\begin{array}{l}\text { Sodium efflux rate } \\
\text { constant (per } h)\end{array}$} & \multirow{2}{*}{$\begin{array}{l}\text { Sodium efflux rate } \\
(\mathrm{mmol} / \mathrm{kg} \mathrm{DS} / \mathrm{h})\end{array}$} \\
\hline & & & $\begin{array}{c}\text { Content } \\
(\mathrm{mmol} / \mathrm{kg} \mathrm{DS})\end{array}$ & $\begin{array}{l}\text { Concentration } \\
(\mathrm{mmol} / \mathrm{l} \text { cell water })\end{array}$ & $\begin{array}{c}\text { Content } \\
(\mathrm{mmol} / \mathbf{k g ~ D S})\end{array}$ & $\begin{array}{c}\text { Concentration } \\
(\mathrm{mmol} / \mathrm{l} \text { cell water })\end{array}$ & & \\
\hline $\begin{array}{l}1 \\
2 \\
3\end{array}$ & $\begin{array}{l}10 \\
20 \\
10\end{array}$ & $\begin{array}{l}2.39 \pm 0.05 \\
2.59 \pm 0.04 \\
2.50 \pm 0.05\end{array}$ & $\begin{array}{l}360=11 \\
292 \pm 7 \\
329 \pm 12\end{array}$ & $\begin{array}{l}146 \div 5 \\
109 \pm 4 \\
130 \pm 5\end{array}$ & $\begin{array}{l}110 \pm 8 \\
185 \pm 7 \\
164 \pm 5\end{array}$ & $\begin{array}{l}46 \pm 4 \\
74 \pm 4 \\
65 \pm 3\end{array}$ & $\begin{array}{l}4 \cdot 25 \pm 0.08 \\
2 \cdot 21 \pm 0.05 \\
2 \cdot 50 \pm 0.11\end{array}$ & $\begin{array}{l}484 \cdot \pm 35 \\
410 \pm 17 \\
409 \pm 21\end{array}$ \\
\hline
\end{tabular}

DS $=$ Dry solids

Conversion: SI to traditional units-Leucocyte potassium and sodium content and concentrations and sodium efflux rate: $1 \mathrm{mmol}=1 \mathrm{mEq}$.

contents and the sodium efflux rate constants in patients with valvular heart disease who were being treated with digoxin and conventional diuretics and compared the results with those in a group of patients with congenital heart disease who had never been in heart failure and who were not on drugs. We also assessed the effects of triamterene on the same measurements in patients with valvular heart disease needing digoxin and diuretics. Leucocytes are excellent cells for studies of electrolyte metabolism. ${ }^{1-20}$ They may be isolated in pure form and are more representative of other body cells than erythrocytes because of their nuclei and aerobic metabolic pathway.

\section{Patients and methods}

The following three groups of patients were studied. (1) Ten patients with cyanotic or acyanotic congenital heart disease who had never been in heart failure and who were not receiving digoxin or diuretics. (2) Twenty patients with valvular heart disease who had been receiving digoxin and either thiazides or frusemide for more than three months; potassium supplements varied from none to $40 \mathrm{mmol}$ (mEq) daily, with a modal value of $23 \mathrm{mmol}$ a day. (3) Ten patients from group 2 who after initial studies had their diuretic regimen supplemented with triamterene $200 \mathrm{mg}$ daily. Potassium supplements were discontinued and the patients studied 10 days or more after the addition of triamterene.

Cellular sodium and potassium and sodium efflux rate constants of leucocytes separated from fresh heparinised blood were measured by a modified version ${ }^{17}$ of Baron and Ahmed's ${ }^{18}$ method. Details of the flux determinations have been reported. ${ }^{7}$ All results are expressed as means $\pm S E$ of mean, a "significant" difference between means indicating $\mathrm{P}<0.05$, as calculated by Student's $t$ test.

\section{Results}

The table summarises the results. In group 1 the leucocyte sodium and potassium content and concentrations did not differ significantly from control values established for the method. ${ }^{7}$ Leucocytes from patients in group 2 showed a highly significant reduction in potassium content and concentration. Leucocyte sodium content and concentration, however, were significantly increased. Leucocytes from patients in group 3 showed a significant increase in potassium content and concentration when compared with those in group 2 . There appeared to be an associated fall in the sodium content, but this did not reach a significant level.

The sodium efflux rate constant fell to nearly $50 \%$ of the control values in the digitalised patients and was marginally but significantly increased in those given triamterene. Plasma sodium was identical in all three groups. The 10 patients in group 2 who eventually formed group 3 had a mean plasma potassium levels of $3.85 \pm 0.12 \mathrm{mmol}$ $(\mathrm{mEq}) / 1$; after treatment with triamterene it rose to $4.54 \pm 0.12 \mathrm{mmol} / 1$.

\section{Discussion}

Cardiac glycosides in vitro inhibit the sodium pump of red cells, leucocytes, and other tissues; indeed, glycoside inhibition is an operational definition of the pump. As sodium and potassium transport is coupled at the cell membrane, these drugs reduce the active transport of sodium out of the cell and potassium into the cell. This leads to a rise in cellular sodium and a fall in cellular potassium.

We found a highly significant difference in the sodium efflux rate constants between digitalised and non-digitalised patients, with a high intracellular sodium level and depletion of the cellular potassium. The potassium depletion may be reversed to a significant extent by triamterene in therapeutic doses. There was a consistent rise in plasma potassium levels in all patients given triamterene, which may have been responsible for the increase in intracellular potassium because leucocyte potassium influx is increased by $25 \%$ when external potassium changes from 3.5 to $4.5 \mathrm{mmol}(\mathrm{mEq}) / 1 .{ }^{21}$ Intracellular potassium rises because there is little change in potassium efflux. Similar changes have been found in erythrocytes.

We did not differentiate between the component of cellular potassium depletion produced by digitalisation and that produced by diuretics. Other investigators, however, have shown that diuretics alone do not usually cause a significant fall in leucocyte levels ${ }^{3}$ and that prolonged treatment with thiazides in non-digitalised patients causes a reduction in whole-body potassium of only $10 \%$ in the group as a whole. ${ }^{4}$ When the sodium pump is slowed it is more difficult for the cell to retain potassium, and the kaliuretic effects of diuretics may act synergistically with cardiac glycosides to further lower cellular potassium levels.

The ability of triamterene to raise cellular potassium levels may make it particularly valuable in digitalis-induced arrhythmias and open-heart surgery, in which cellular potassium depletion jeopardises myocardial function. We are currently examining whether triamterene can significantly increase myocardial potassium levels in patients undergoing cardiac surgery and also whether the effects on the leucocytes are related solely to a rise in extracellular potassium or whether the drug has a specific effect on the cell membrane. The similar efflux rates in groups 2 and 3 suggest that "passive" sodium transport is unaffected, so that any change that occurs must be in the "active" transport system.

We acknowledge the financial support of Smith Kline and French Ltd and the Wellcome Trust. Dr Hoppe, of Smith Kline and French, generously supplied the triamterene used in this study.

\section{References}

${ }^{1}$ Harrison, T R, Pilcher, C, and Ewing, C, fournal of Clinical Investigation, $1930,8,139$.

2 Schimart, G, et al, fournal of Thoracic and Cardiovascular Surgery, 1966, $52,126$.

${ }^{3}$ Edmonson, R P S, et al, Lancet, 1974, 1, 12.

4 de Deuxchaisnes, C M, et al, Lancet, 1961, 1, 681.

5 Wilkinson, P R, et al, Lancet, 1975, 1, 759.

6 Glynn, I M, Fournal of Physiology, 1957, 136, 148.

${ }^{7}$ Hilton, P J, and Patrick, J, Clinical Science, 1973, 44, 439.

8 Muller, P, Circulation Research, 1965, 17, 46.

- Seller, R H, et al, Clinical Research, 1972, 20, 413.

${ }^{10}$ Kettleworth, M, Nowers, A, and White, R, British fournal of Pharmacology, 1972, 44, 165.

11 Astrup, J, Scantinavian fournal of Clinical and Laboratory Investigation, 1974,$33 ; 11$.

12 Krogsgaard, A R, and Kragh, P L, Ugeskrift for Laeger, 1964, 126, 298.

13 Sperber, RJ, and De Graff, A C, American Heart fournal, 1965, 69, 134.

${ }_{14}$ Morin, Y, Turmel, L, and Fortier, J, American Heart fournal, 1965, 69, 195.

15 Taggert, P, and Slater, J D H, Clinical Science, 1970 38, 26 P.

${ }_{16}$ Regan, T J, et al, fournal of Clinical Investigation, 1967, 46, 1657.

17 Patrick, J, and Hilton, P J, Clinical Science, 1973, 44, 457.

18 Baron, D N, and Ahmed, S A, Clinical Science, 1969, 37, 205.

19 Patrick, J, and Bradford, B, Clinical Science, 1973, 44, 439.

${ }^{20}$ Patrick, J, et al, Clinical Science, 1972, 43, 669.

${ }^{21}$ Hilton, P S, et al, Clinical Science and Molecular Medicine, 1975, 49, 385. 